\title{
Article
}

\section{The Colonial Project of Gender (and Everything Else)}

\author{
Sandy O'Sullivan (1)
}

check for

updates

Citation: O'Sullivan, Sandy. 2021. The Colonial Project of Gender (and Everything Else). Genealogy 5: 67. https://doi.org/10.3390/ genealogy5030067

Received: 1 May 2021

Accepted: 14 July 2021

Published: 16 July 2021

Publisher's Note: MDPI stays neutral with regard to jurisdictional claims in published maps and institutional affiliations.

Copyright: (C) 2021 by the author. Licensee MDPI, Basel, Switzerland. This article is an open access article distributed under the terms and conditions of the Creative Commons Attribution (CC BY) license (https:/ / creativecommons.org/licenses/by/ $4.0 /)$.
Department of Indigenous Studies, Macquarie University, Sydney 2109, Australia; sandy.osullivan@mq.edu.au

\begin{abstract}
The gender binary, like many colonial acts, remains trapped within socio-religious ideals of colonisation that then frame ongoing relationships and restrict the existence of Indigenous peoples. In this article, the colonial project of denying difference in gender and gender diversity within Indigenous peoples is explored as a complex erasure casting aside every aspect of identity and replacing it with a simulacrum of the coloniser. In examining these erasures, this article explores how diverse Indigenous gender presentations remain incomprehensible to the colonial mind, and how reinstatements of kinship and truth in representation fundamentally supports First Nations' agency by challenging colonial reductions. This article focuses on why these colonial practices were deemed necessary at the time of invasion, and how they continue to be forcefully applied in managing Indigenous peoples into a colonial structure of family, gender, and everything else.
\end{abstract}

Keywords: queer First Nations; queer Indigenous; non-binary Indigenous; First Nations museums; First Nations gender; colonial gender

\section{The Colonial Project of Gender (and Everything Else)}

A central tenet of the project of colonisation is a reductive examination of the lives of Indigenous peoples, casting them as dysfunctional, inferior versions of colonial home state actors (Bodkin-Andrews and Carlson 2016, p. 789). The project of embedding these ideas in colonial lands also relies on the colonial state actors' disconnection from their own deep histories, wherein they replace their beliefs and nuances with faith in the colonial state and enact this belief on others. This denial of anything not in service to the state was then, upon invasion and incursion of Indigenous lands, extended to controlling the behaviour, relationships, and the actual embodiment of Indigenous peoples (Smith 2013, p. 45). While the focus across this article is the exploration of the methods of denial and erasure of genders outside of the gender binary, there is also a recognition that this, while devastating in itself, is a marker of how narratives of exclusion are managed in the practices of colonisation.

Central to any exclusion in managing Indigenous peoples, is asserting meaning and value by engaging markers to commodify not only the bodies of existing Indigenous people, but also past and future Indigenous people. This is present in the way that gender roles are reformed through colonial restrictions as a tool to align family and kinship structures so that they mimic privileged European family systems at the moment of first invasion (TallBear 2018, pp. 146-47; Behrendt 2000, p. 354). Through the construction of an exclusive, and excluding ancestral relationship, this structure proposes relationships of meaning that relate only from progenitor to direct issue. The modern nuclear family as a repeating pattern is then privileged. This process, crucially for Indigenous peoples, replaces existing kinship structures with a linear view of relationships, family, and accountabilities to the state and to each other (Nash 2005, p. 449). To decimate kinship structures that variously occupy relationality outside of this linear path requires mimicry of an accepted European system that entails: a mother, who is a woman; a father, who is a man; and then a child who is coded male or female to ensure a continuation of the gender roles assigned and the commodified reproduction of their future descendants (Kramer 2011, p. 381). The extended family (in the vernacular of the British colonial state) then becomes segmented 
into reproductions of the linear family state, joined together through a common ancestor. In this structure, grandmother and grandfather were once mother and father, and they become either carers or cared for (Smith 2013, pp. 45-46). The roles outside of these are blurred in the chronology set through the colonial project, as the primary concern becomes a focus on continuation of a reproductive line. This is made more difficult when the system, and the act of genealogical charting, asserts a reproductive kinship, and denies a place for relationships outside of linear reproduction, which then becomes framed as a break in the integrity of the idea of family (TallBear 2020, p. 473).

Within each of these reproductive roles are the binary genders of male and female, clearly marked and stated as gender assignation from birth (Gill-Peterson 2018, p. 26). In order to understand the need for these binaries in the colonial project of managing gender, people, and everything else, it is important to consider how the Western system imposed through colonial incursion is exclusively interested in an unbroken line of blood connection and direct descendancy (Strathern 2017, p. 20). It consistently pits this descendancy against a broken line framed as adoption, foster care, or 'distant' relative care, setting these as atypical family structures. The writer and performer Steven Oliver (Kuku-Yalanji, Waanyi, Gangalidda, Woppaburra, Bundjalung, and Biripi), in their 2021 one-person show Bigger and Blacker, explains the lack of understanding of extended kinship systems by non-Indigenous people in a joke. Oliver describes how white people frame the distance away from family members to them, i.e., 'second-cousin, once removed', in contrast to Aboriginal people framing these relationships as closeness, where brothers can be cousins, and cousins can be unrelated (Oliver 2021) or (using the vernacular of the colonial kinship system) distantly related.

These ideas require Indigenous peoples to be treated as objects who are excluded from what Moreton-Robinson refers to as the, 'possessive investment in whiteness,' as a feature of asserting sovereignty (Moreton-Robinson 2015a, p. 76). Calls for sovereignty posit that Indigenous people hold no inherent relationship to the colonial state beyond being managed as pawns and observed as inferior subjects (Moreton-Robinson 2015b, p. 139). These practices of distancing kinship are enacted in the colonial system of Australia as a means to reproduce the constrained 19th century family formation (TallBear 2013, p. 4). These ideas are challenged through the concerted efforts of Indigenous-led initiatives that assert kinship as a means to care for children beyond the colonial idea of family (TallBear 2013, p. 4; Dudgeon and Bray 2019). These recalibrations from within our communities are still managed and overseen by state-endorsed models, but the strong leadership within community-led organisations challenges this. This response has been mapped out as essential as we continue to challenge the fallout of one of the most heinous acts in the contemporary colonial era: the forced and violent removal of children from families, where individuals and families were seen as abject and not fit to make decisions over their futures (Bennett and Gates 2019, p. 605). The challenge for Indigenous-led groups that work against the shackles of the colonial state in restating kinship systems that challenge these structures, is the further challenge to manage this while also breaking down the statemandated hierarchies of responsibilities and relationships that they fall within (TallBear 2013, pp. 6, 14-15). There is also no clear place in these genealogical chartings, which represent legal responsibilities, to locate or make meaning of extended kinship relations nor the complexity of connection found across Aboriginal and other First Nations' communities outside of reproductive issue (TallBear 2018, p. 149). They are seen as a disconnect, rather than a connection. Furthermore, the benefit derived from reconsidering the role of gender outside of the binary in these colonial constructions of family and responsibility, is to understand that Indigenous uniqueness separate to the coloniser were intentionally erased from the colonial record in order to make us same (Driskill 2004, p. 51; Smith 2010, p. 58).

\section{Kinships: Restorative and Regenerative}

In spite of these colonial incursions, First Nations communities across the world continue to apply their own kinship forms and relationality extending beyond blood- 
connection or direct line. Early and intentional colonial erasures formed from managing the reproductive rights of First Nations' communities are fractured within the colonial record that is often relied on to frame evidence. Alison Whittaker (Gomeroi) has written on the absence of evidence not being evidence in itself when it comes to queerness of gender or sexuality across this continent. Whittaker argues that the contemporary presence of queer Indigenous people across the continent belies assertions that queerness is the remit of white progressives, and challenges a reductive reckoning of the complexity of who Indigenous people both were and are (Whittaker 2015, p. 226). Across the colonised North American continent, the modern term, Two Spirit/2-Spirit, has been formulated in recent decades to describe contemporary and historic genders and sexualities that were erased through the colonial record and to provide, as Alex Wilson (Opaskwayak Cree) suggests, a connection from the past to the present (Wilson 1996, p. 303). Not all First Nations' communities connect diverse gender and sexuality, nor do they have names that articulate these connections or this divergence from the colonial binary. There is, however, a growing body of knowledge that suggests that, in spite of the erasures that Whittaker describes, historic renderings the challenge binary genders and reproductive essentialism were, and continue to be, present (Day 2020, p. 368; Smith 2010, p. 47).

Taking control of modern narratives that challenge the colonial project by locating ways to recall and restructure gender and sexualities is key to much of the queer work being done by those who inhabit First Nations' communities (Smith 2010, p. 47). In Australia, the terms Brotherboy and Sistergirl, are newer terms (albeit still framed within the traditional binary) that some people use to describe their transmasculine and transfeminine selves (Farrell 2017, p. 1). These terms, and other terms yet to come, allow for an expansive kinship structure to be calibrated and reframed. They form a challenge to the forced induction of communities into western religious practices that exclude and demonise relationships that fall outside of linear family structures (TallBear 2018, p. 149). They provide a level of resistance (Farrell 2017, p. 1), even as there remains work to be done for these communities to accept and support queerness in the push/pull of the colonial project (Day 2020, p. 368).

\section{Colonial Incursion: Inconsistent and Erasive}

These religious constrictions are not a relic of the past, but are held in current practice. This provides evidence of the ongoing nature of colonial incursion, that persistently works to erase difference. In 2019, the Congregation for Catholic Education for Educational Institutions issued a report, Male and Female He Created Them: Towards a Path of Dialogue on the Question of Gender Theory in Education. This report, in use globally across Catholic educational institutions, seems less dialogue and more edict, applying a closed ideal of family as a model to assert the gender binary and exclude all non-nuclear family forms. Across the Report there is a persistent assertion that binary assigned genders are immutable, focused on reproduction, and dangerous when expanded upon (Congregation for Catholic Education for Educational Institutions 2019, pp. 3, 5, 7, 11). The Report insists on certainties around family formation, in the form of a mother and father, and argues that this is essential because it 'allows the child to construct his or her own sexual identity and difference' (p. 14). In complete contrast, the same document argues against difference or alternate ways in which the understanding of gender should be described and encouraged (pp. 3, 14). The report further asserts that the use of reproductive assistance reduces 'a baby to an object in the hands of technology and science' (p. 15) and then, by contrast, promotes medical intervention for 'cases where a person's sex is not clearly defined', by suggesting that 'it is medical professionals who can make a therapeutic intervention' (p. 13). As with many researchers who challenge the idea of gender, the creators of the document seem confounded by the idea that gender may be separate to sex, even when, in the case of children who are born with, what they frame as, ambiguous sex organs (p. 13), there are clear choices being made for the child on their gender or assigned sex, by others. In the same missive, the document, that criticises what it frames as 'gender ideology' as an 
emerging and modern construction, and also criticises that 'this new range of relationships become 'kinship" (p. 9) and thus gaslights every historic iteration of gender diversity and sexuality outside of the heteronormative, and every Indigenous iteration of kinship that challenges the western patriarchal system.

In reading this work alongside Kim TallBear's Making Love and Relations beyond Settler Sex and Family (2018), where we are presented an alternative way of locating family, what is striking is not only the expansive way that relations are framed, but the ways in which TallBear (Sisseton Wahpeton Oyate) proposes work to arrive at a point where Indigenous genders and sexualities become freed of the colonial trappings of the church and state (TallBear 2018, p. 155). TallBear challenges sexual and gender norms imposed by the colonial state, and proposes a similar pathway to Whittaker's assertion on resistance of framing the past as pure, the present as progressive, and the pathway between the two as immovable or controlled by colonial actors, locating these as deeply problematic trappings of colonial pronatalism and heteronormativity (p. 153). TallBear and other Indigenous scholars engage expansive ways of countering the closing off of colonial understandings of Indigenous peoples, their genders, and their sexualities. For instance, Alex Wilson documents the work within N'tacinowin inna nah': Our Coming in Stories (Wilson 2008), as a process of incorporating the complete Two-Spirit person in a way that expands the idea of who a community is, rather than requiring them to conform to the edicts of that community.

In contrast, religious organisations, such as the Catholic Church, maintain that difference outside of the fundamental binary is to be avoided (Congregation for Catholic Education for Educational Institutions 2019). Yet people from Anastasia the Patrician to St Marina/Marinos, the latter of which was made saintly by their very act of denying their birth gender, and canonised on this basis, have behaved outside of what the Church frames as 'femininity' (Grayson 2009, p. 143). St Marina/Marinos presents as male to join a monastery, is accused of fathering a child with a woman from the town, is then cast out (as the canonical documents suggest) only to care for the child, in spite of their obvious 'innocence' in this act. Upon death, their birth sex is discovered and their acts form the basis of their canonisation (Grayson 2009, p. 143). These, and other figures within the Church who perform outside of the acceptable gender norms stated in the previously mentioned report, hold venerated positions in the literal canon of the Catholic Church. With the confusion of gender roles and gender assignation that the previously mentioned Congregation for Catholic Education for Educational Institutions report makes evident, it is surprising that these saints continue to be revered in the modern church. Surely they represent a confusion of gender, as it is explained in the document, and surely their acts cannot be endorsed?

It is also important that beyond the way that the report frames the risky adoption of ideas of 'gender' as opposed to 'sex', it also frames factors that seem to support complexity in the binary gender that sits outside of the experience of being simply born into a sex. In particular the term 'femininity', in the report (pp. 10,18-19, 21), is either described as a role of difference, or as an aspect of reproduction, which would be unavailable to any cisgender women who are unable, or chose not to, reproduce. In this case what makes them 'feminine', appears to be their equal opposite to masculinity in affect, and not their birth sex (p. 18). The document also speaks to differences in women to men using the same idea of affect, by suggesting fundamental attitudinal difference, as it invokes and quotes the 2004 Letter to Bishops of the Catholic Church on the Collaboration of Men and Women in the Church and in the World, wherein it describes that 'women's 'capacity for the other' favours a more realistic and mature reading of evolving situations', so that '... a sense and a respect for what is concrete develop in her, opposed to abstractions which are so often fatal for the existence of individuals and society' (p. 10). In creating a dyadic separation, they promote a world in which women have the ultimate responsibility for the bad acts of men. They also frame women as having, ' . . a unique understanding of reality', suggesting that women are required to be pragmatic, presumably in contrast to men. Given 
these promoted differences in affect, to then introduce more than two gender binaries could, in fact, confound this binary ideal that seems also focused on contrasting intent.

\section{Representations and Colonising Decisions That Erase and Confound Gender}

But where does reliance on the restrictive form of family, gendered roles and gender come from in the colonial mindset when recalling the past and making sense of other cultures? In order to explore this, I ask the reader to come on a journey that considers the way that artefacts and objects from the past, now held within museums, have been calibrated and recalibrated to erase and restrict their meaning and relevance.

Between 2010 and 2019, I undertook a major research project exploring the capacity for national museums to engage with First Nations' communities within their own geographic region. It focused specifically on how those communities work with museums to reflect or represent what was meaningful for them by asking a central question of what is effective in that representation, both for the museum and for the community. The project required a broad review of 470 museums, and included social history and natural history museums, museums with encyclopaedic approaches, and museums that took visitors through a timeline of history. Some museums were focused and run by First Nations' communities. Others, such as the National Museum of the American Indian (NMAI), were pan-Indigenous and used a survey approach where they engaged and represented multiple communities. Still others had a broader brief that included First Nations' within the jurisdictions of the museums, such as the national museums of Australia and the United States, two countries originally selected as sites of interrogation.

While engagement with contemporary communities was central to the discussion, many of the museums were focused on the archaeological record, and often failed to perform ongoing engagement with these communities to make sense of artefacts associated with deep time (O'Sullivan 2016, p. 38). Engagement with contemporary communities, however, was also not always welcomed by those communities. In part this was because museums have been sites of extreme colonial violence, with requests for the return of the human remains of past generations held in museums and archives, denied or dismissed until recent years. This work on repatriation was the central work I had engaged with prior to beginning this project. As a Wiradjuri person, like many other Indigenous people, I was deeply concerned about the ways in which museums had enacted the colonial project through the gathering of not only our artefacts and objects of our past, but also in how they had failed to comprehend the complexity of what it means for our ancestors to be treated as objects in an archive (O'Sullivan 2016, p. 35). From this position came the review project, that interrogated how these spaces engaged with communities and heard their voices, their needs for repatriation and their desire to represent and interpret their own communities and peoples.

As a major part of this review, I sought to understand the ways in which First Nations' peoples were being represented in their home, colonised countries. The project had begun at the time that the deployment of the Native American Graves Protection and Repatriation Act (NAGPRA) was in full swing, and this provided opportunities for First Nations' communities in the US to look at their own engagements and to define their own participation in the ongoing project of inclusion in museums. In particular outside of this work of repatriation, NAGPRA built capacity within Communities for managing collections and worked towards rehabilitating the relationship between non-Indigenous museums and First Nations' museums and communities. This idea of self-representation was the other present concern for many First Nations' peoples, coming through as a clear outcome from the discussions held across the first part of this project in 2010 ( $\mathrm{O}^{\prime}$ Sullivan 2016, p. 37).

During the early stages of the research, as I conducted face-to-face yarning circles, focus groups that allowed free discussion of concerns and suggestions (O'Sullivan 2016, p. 37). Elders were asked to prioritise the museums and places that should be included in this study. Yarning circles are often used by First Nations' communities to discuss important 
business, and differ from focus groups in the way that they centre the relationality of the members. The researcher will acknowledge the Nation on which they are meeting, usually declare their own Indigenous nation (or non-Indigenous status and background) and their relationship to the community to which they are speaking. Other participants will do the same, and the scene is set for open discussions that provide deep background for the research (Carlson and Frazer 2018). Listening to Elders in this forum was essential in understanding the difficult history that they had, the concerns that they felt, and the expectations that they placed on museums to represent and engage with our Communities.

I began my introduction with my own history of working in repatriation of human remains from museums back to First Nations' communities. I then explained that the project was already set to include certain museums across two of these colonially constructed countries, the first being Australia, as host and funder of the research, and as the site of my own Wiradjuri Nation. The United States was also included as it represented a similar colonial structure of hundreds of linguistically different communities, that both dispossessed First Nations' peoples and accommodated (albeit with levels of paternalism) self-determination for those communities. The museums included were the National Museum of the American Indian of the Smithsonian Institute, the National Museum of Australia, as well as leading museums that held substantial collections. Museums that were run by First Nations communities to represent their own nations were also included, such as the Mashantucket Pequot Museum in Connecticut. The basis for inclusion was that each museum or keeping place held a substantial part of their collection devoted to First Nations' representation in some form, and that their approach engaged with contemporary communities.

In one of the initial yarning circles, an elder asked me why I wasn't looking at England. I assumed the Elder was confused about the nature of the project and I explained that unlike my previous work on repatriation in colonial spaces, this project focused on museums that were located on, or near, First Nations' lands, or within that same colonised country. The Elder was visibly annoyed with me, and stated that 'You can tell a lot about how people represent others by how they represent themselves' (O'Sullivan 2016, p. 37). Their idea, far more complex than the ones I had formulated at the time, proposed that within coloniser lands, an exploration of the colonisers own long history presents a deeper understanding of how their own colonial practices are shaped. Furthermore, it ponders how, in the context of this research, these understandings affect the ways in which First Nations' Peoples are represented in their museums. Britain, then, became included (not unproblematically) and it was there that a number of issues around not just the depiction of their own deep history, but their fixed depictions of gender and gendered affect, started to surface.

\section{Historical Incursions: Who Decides Gender?}

In the Ice Age Art exhibition of the British Museum and its corresponding book, Jill Cook explores the modern mind told through Ice Age artmaking focused on their contemporary human figurines that form identities and meaning for the corresponding communities in European deep time (Cook 2013). For a country that presented extreme resistance to my questions on the connection to a deep history of past peoples ( $\mathrm{O}^{\prime}$ Sullivan 2016, p. 38), Cook's work on the European mind of more than 40,000 years, represented an insight into a connection that is often not found across British museums that frequently only see ethnicity in others (O'Sullivan 2016, p. 37). These figurines, Cook posits, suggest significant complexity of thought, and the work is a masterpiece of connecting deep time history with contemporary ways of imagining humanity's place in the world (Cook 2013, p. 108). However, Cook, in exploring these meanings, consistently assigns a gendered reading to the figurines that begins with a conflation of sexing and gendering, and extends to similar language of gendered characteristics of masculinity and femininity, used in the previously mentioned document from the Vatican.

When discussing a figurine in mammoth ivory found at Laugerie Basse that is roughly dated to $17,000 \mathrm{BCE}$, Cook proposes that the figure's 'femininity is determined by the 
vulva slit clearly marked by an incision' (Cook 2013, p. 226). In this instance, beyond a conflation of gender and sexing of the figurines, there is a broader reach made where corroborating information cannot be found, assuming a binary of genders and affect on the basis of a sexing. The starting point is that figurines become sexed rather than gendered, and then significant embellishments to sexing that Cook, and many others across the broad imagining of the past within an archival-focused retelling, use, applying highly gendered terms such as 'femininity' to code that sexing. 'Femininity', in particular is used frequently throughout Cook's description as an interchangeable idea of a sexed or gendered figure (pp. 224-41). That the terms of masculinity and femininity are used interchangeably to provide detail that affirms binary genders speaks to what reads as a reductive reckoning connected to the curator/writer's own gaze, erasing any potential reading of the archive for divergence from the binary.

Venus of Willendorf is one of the best known European Ice Age figurines, and has become the embodiment of the conflated female/woman/fertility character as a deep time artefact (Karayanni 2009, p. 449; Tripp and Schmidt 2013, p. 56; Kuiper 2016). These nearly complete figurines are often interpreted variously as womanly, female, and as symbols of fertility, regardless of available corroborating evidence. Cook describes the archaeologist Karel Absolon's description of pieces found in stylised, disconnected body parts in the form of wearable ivory as 'grotesque' suggesting the 'highest degree of sexual-biological hyperstylization' that the '.. artist neglected all that did not interest him stressing his sexual libido only where breasts are concerned-a diluvial plastic pornography' (Cook 2013, p. 68). This highly gendered analysis suggests a modern ontological frame, a male gaze, neither of which are backed up with evidence from the archaeological record to suggest gender or sexualization. The entire story contains a confabulation that frames actor, intent, and, of course, gender(s).

Characters framed as male often also engage ideas of fertility. Often depicted with erect penises, or showing a level of strength, their physical characteristics are listed to become the embodiment, which then correlates to the binary male fertility. But what evidence exists that this was the intent of the makers? And what right do those who curate have in casting their own ideas of gender on these figurines? The figure of Lion Man, one of the oldest ice-age figurines at approximately 40,000 years old, becomes framed, at least in English, as male (Cook 2013, p. 30). Although this interpretation is challenged, Cook airs these challenges by weighing up the evidence based on body parts that, apparently, demonstrate maleness as a pivot opposite to femaleness, with no consideration for other ideas around gender, and as a process of determining gender. Essential to these assertions is that gender and gender typing mattered as much to ancient peoples as they do to those cataloguing and writing about them. Does it matter if Venus of Willendorf or Lion Man are gendered at all? What does it tell us beyond a contemporary obsession with the gender binary? If there is ambiguity, it is almost always determined to be gendered according to the binary. And where we see genders represented, or even contested outside of the binary, they are often configured as metaphysical and not representative of actual, living people, as in Lion Man: half human, half lion. Are then characters outside of the binary only available as abject or alien representations, rather than figurative representations of living people from the past?

The criticisms are not of Cook's otherwise complex rendering of the ice-age human's mind, nor of other curators and writers who have sought to imagine the past in order to present it for the engagement of a modern audience. While Cook acknowledges in their work that these Ice Age figurines cannot be truly known to us (p. 107), in persisting in this gendering they provide insight into the problematic position that comes from relying on the values of those telling the story and those who control the narrative. The risk is that in the retelling of gender, an overemphasis on identifying the gender of these figurines, as though it provides greater insight to those contemporary actors, reduces rather than expands the ways in which peoples across deep time can be imagined. 


\section{Conclusions: Yindyamarra-Respect, Relationality, and Inclusion}

For contemporary Indigenous peoples, this reduced representation acts as a marker for our continued management within the colonial project, through the colonial structures and restrictions still held in place. As the Elder suggested during the yarning circle, 'You can tell a lot about how people represent others by how they represent themselves'. Palawa scholar, Ambelin Kwaymullina's poetic summary of colonisation as 'the long con' recognises the persistent lengths that colonial structures will extend to erase the truths and complexities of Indigenous people (Kwaymullina 2020). Museums are the ultimate problematic for Indigenous Peoples: they are spaces that have collected, reduced and displayed our very bodies, and that remain spaces where our past and our present are held. If we cannot insist on the complexity of genders and gender expression, and reduce only to ideas of what can be proven through the colonial record, we will remain static and will succumb to the strictures of the colonial project of managing gender and everything else.

While a curator analysing deep time artefacts of a culture distantly removed is restricted by available evidence, contemporary Indigenous peoples are writing their own stories and are refusing to have their sovereign selves be contained. Wiradjuri writer and scholar Anita Heiss has written about the impossibility of writing on the continent, now known as Australia, without the presence and permission of First Nations' peoples. In considering her argument for both Indigenous people writing their own stories, and the respectful inclusion of the figures of Indigenous peoples by non-Indigenous writers, she has deployed a Wiradjuri expression: yindyamarra, which she interprets as to ' ... respect, honour, be polite' (Heiss 2021). It insists on inclusion, and for that inclusion to only be through permission and an ongoing conversation. Kwaymullina's 'long con' presumes that this is a constant challenge for those engaged on both sides of colonisation. As a process that denies and erases, to then include and respect is an important journey. In the case of writing the complexity of gender, that may mean for museum curators, writers and those tasked with supporting better understandings of the uncontained truth of Indigenous gender of the past, that engaging yindyamarra and revealing our own biases on gender, is key to providing a story that reveals, rather than erases.

Funding: Funding for the museums study was provided by the Australian Research Council.

Institutional Review Board Statement: The museums study was conducted according to the guidelines of the Australian Institute of Aboriginal and Torres Strait Islander Studies Guidelines for Ethical Research and approved by the Human Research Ethics Committee of Batchelor Institute of Indigenous Tertiary Education on the 3 May 2010 (no. HREC-039-048).

Informed Consent Statement: Informed consent was obtained from all subjects involved in the study.

Conflicts of Interest: The author declares no conflict of interest.

\section{References}

Behrendt, Larissa. 2000. Consent in a (Neo) Colonial Society: Aboriginal Women as Sexual and Legal 'Other'. Australian Feminist Studies 15: 353-67. [CrossRef]

Bennett, Bindi, and Trevor Gates. 2019. Teaching cultural humility for social workers serving LGBTQI Aboriginal communities in Australia. Social Work Education 38: 604-17. [CrossRef]

Bodkin-Andrews, Gawaian, and Bronwyn Carlson. 2016. The legacy of racism and Indigenous Australian identity within education. Race Ethnicity and Education 19: 784-807. [CrossRef]

Carlson, Bronwyn, and Ryan Frazer. 2018. Yarning circles and social media activism. Media International Australia 169: 43-53. [CrossRef]

Congregation for Catholic Education for Educational Institutions. 2019. Male and Female He Created Them: Towards a Path of Dialogue on the Question of Gender Theory in Education. Vatican City: Catholic Truth Society.

Cook, Jill. 2013. Ice Age Art: The Arrival of the Modern Mind. London: British Museum Press.

Day, Madi. 2020. Indigenist Origins: Institutionalizing Indigenous Queer and Trans Studies in Australia. Transgender Studies Quarterly 7: 367-73. [CrossRef]

Driskill, Qwo-Li. 2004. Stolen from our bodies: First Nations two-spirits/queers and the journey to a sovereign erotic. Studies in American Indian Literatures 16: 50-64. [CrossRef]

Dudgeon, Pat, and Abigail Bray. 2019. Indigenous relationality: Women, kinship and the law. Genealogy 3: 23. [CrossRef] 
Farrell, Andrew. 2017. Archiving the Aboriginal Rainbow: Building an Aboriginal LGBTIQ Portal. Australasian Journal of Information Systems 21. [CrossRef]

Gill-Peterson, Jules. 2018. Histories of the Transgender Child. Minneapolis: University of Minnesota Press.

Grayson, Saisha. 2009. Disruptive Disguises: The Problem of Transvestite Saints for Medieval Art, Identity, and Identification. In Medieval Feminist Forum: A Journal of Gender and Sexuality. Iowa: Society for Medieval Feminist Scholarship, vol. 45, no. 2. pp. 138-74.

Heiss, Anita. 2021. Want to Write the Great Australian Novel? You Need to Engage with Indigenous Australia First. Available online: https: / / www.theguardian.com/books / 2021/apr/28/want-to-write-the-great-australian-novel-you-need-to-engagewith-indigenous-australia-first?CMP=twt_books_b-gdnbooks (accessed on 15 July 2021).

Karayanni, Stavros Stavrou. 2009. Sacred embodiment: Fertility ritual, mother goddess, and cultures of belly dance. Religion and the Arts 13: 448-63. [CrossRef]

Kramer, Anne-Marie Caroline. 2011. Kinship, affinity and connectedness: Exploring the role of genealogy in personal lives. Sociology 45: 379-95. [CrossRef]

Kuiper, Kathleen. 2016. Venus of Willendorf. Encyclopædia Britannica Inc., vol. 16. Available online: https://www.britannica.com/ topic/Venus-of-Willendorf (accessed on 15 July 2021).

Kwaymullina, Ambelin. 2020. Living on Stolen Land. Broome: Magabala Books.

Moreton-Robinson, Aileen. 2015a. Nullifying Native Title: A Possessive Investment in Whiteness. In The White Possessive: Property, Power, and Indigenous Sovereignty. Minneapolis: University of Minnesota Press, pp. 65-78.

Moreton-Robinson, Aileen. 2015b. Writing off Sovereignty: The Discourse of Security and Patriarchal White Sovereignty. In The White Possessive: Property, Power, and Indigenous Sovereignty. Minneapolis: University of Minnesota Press, pp. 137-52.

Nash, Catherine. 2005. Geographies of relatedness. Transactions of the Institute of British Geographers 30: 449-62. [CrossRef]

O'Sullivan, Sandy. 2016. Recasting Identities: Intercultural understandings of First Peoples in the national museum space. In The Routledge International Handbook of Intercultural Arts Research. Edited by P. Burnard, E. Mackinlay and K. Powell. London: Routledge.

Oliver, Steven. 2021. Bigger and Blacker. Meanjin: La Boite Theatre.

Smith, Andrea. 2010. Queer theory and native studies: The heteronormativity of settler colonialism. GLQ: A Journal of Lesbian and Gay Studies 16: 41-68. [CrossRef]

Smith, Linda Tuhiwai. 2013. Decolonizing Methodologies: Research and Indigenous Peoples. New York: Zed Books Ltd.

Strathern, Marilyn. 2017. Naturalism and the Invention of Identity. Social Analysis 61: 15-30. [CrossRef]

TallBear, Kim. 2013. Native American DNA: Tribal Belonging and the False Promise of Genetic Science. Minneapolis: University of Minnesota Press.

TallBear, Kim. 2018. Making Love and Relations beyond Settler Sex and Family. In Making Kin Not Population. Edited by Adele E. Clarke and Donna Haraway. Chicago: Prickly Paradigm Press, pp. 145-66.

TallBear, Kim. 2020. Identity is a poor substitute for relating: Genetic ancestry, critical polyamory, property, and relations. In Routledge Handbook of Critical Indigenous Studies. Edited by Brendan Hokuwhitu, Aileen Moreton-Robinson, Linda Tuhiwai-Smith, Chris Anderson and Steve Larkin. London: Routledge, pp. 467-78.

Tripp, Allison J, and Naomi E. Schmidt. 2013. Analyzing fertility and attraction in the paleolithic: The venus figurines. Archaeology, Ethnology and Anthropology of Eurasia 41: 54-60. [CrossRef]

Whittaker, Alison. 2015. The Border Made of Mirrors. In Colouring the Rainbow: Blak Queer and Trans Perspectives, Life Stories and Essays by First Nations People of Australia. Edited by D. Hodge. Mile End: Wakefield Press.

Wilson, Alex. 1996. How we find ourselves: Identity development and two spirit people. Harvard Educational Review 66: 303-18. [CrossRef]

Wilson, Alex. 2008. N'tacinowin inna nah': Our Coming in Stories. Canadian Woman Studies 26: 193-99. 